\title{
USING OF 24 HOURS FOOD RECALL METHOD TO STUDY NUTRITIONAL STATE FOR PREPARATORY SCHOOL STUDENTS \\ Abd El-Gawwad, A. I. ${ }^{*}$; G. H. M. Habib** ; Sh. M. El-Shahawey ${ }^{\star}$ and Y. K. Abd El-Latif* \\ * Food Industries Dept., Fac. of Agric., Mans. Univ., Egypt. \\ ${ }^{* *}$ Home Economics Dept., Fac. of Specific Education., Tanta Univ., Egypt
}

\begin{abstract}
This study was carried out to evaluate the nutritional state for preparatory school students aged from (12-15 years) by using of 24 hours food recall method. Questionnaire results indicated that the content of all meals for energy, vitamin $A$, vitamin $C$, vitamin $D$, vitamin B1(Thiamin), niacin, vitamin B6, calcium, phosphorus and Zink were less than those of Recommended Daily Allowances (RDA, 1989) for both sexes, while total iron and magnesium for females and vitamin $E$ for males. Results indicated that total protein, carbohydrate, vitamin B2 (Riboflavin), vitamin B12, folate and sodium were more than those of RDA for both sexes. The content of total iron and magnesium for males, and vitamin $E$ for females were more than those of RDA. From above mentioned results, that intake extra content from all meals for energy, vitamin $A$, vitamin $C$, vitamin $D$, vitamin $B 1$ (Thiamin), niacin, vitamin $B 6$, calcium, phosphorus, Zink for both sexes, while total iron and magnesium for female, and vitamin $E$ for male is recommended.

Keywords: 24 hours food recall, Recommended Daily Allowances, Questionnaire and Preparatory School.
\end{abstract}

\section{INTRODUCTION}

Nutrition has a great influence on the growth process of an individual. During late childhood and early adolescence, a person begins to develop at an accelerated rate. At this time, the nutritional value of the food a person consumes becomes very crucial to his or her biological and intellectual development. Failure to consume an adequate diet at this time can disrupt normal growth and pubertal development (Lifhithz et al., 1993).

Adolescence is one of the most dynamic and complex transitions in the life span. The adolescence period is the transitory stage from childhood to adulthood, it is a unique stage process of growth and development; this period is accompanied by series of physical, physiological, biochemical, hormonal and psychological changes that occur during the growth spurt (Perry, 2000). Rapid physical growth creates an increased demand for energy and nutrients. Total nutrients needs during adolescence are higher than any other time in the life cycle, and failure to consume an adequate diet during the time can potentially affect growth and sexual maturation (Owen, and Frankle, 1986 and Story, 1992). So this stage is a critical period of human life (Pipes, 1989).

A dietary recall is a retrospective method of dietary assessment where an individual is interviewed about their food and beverage consumption 
Abd El-Gawwad, A. I. et al.

during a defined period of time, typically the previous day or the preceding 24 hours. Recall of intake over a longer time period is problematic due to the limitations of memory. Several national surveys use the 24-hour recall method because of its high response rate and its ability to obtain detailed information. The interview can be carried out in person, by telephone or increasingly via the Internet. In the Norwegian arm of the EPIC study no significant differences in the dietary data obtained were found when face-toface 24-hour recalls were compared to telephone 24-hour recalls (Brustad et al, 2003).

This work aimed to evaluate the nutritional status of preparatory school students aged from 12:15 years using 24 hours recall method and comparing with Recommended Dietary Allowances, (RDA, 1989).

\section{MATERIALS AND METHODS}

\section{Materials:}

Sample size:

This study was carried out on 150 preparatory schools students divided into 75 male and 75 female. The age of the sample ranged between 12 to 15 years old in Menyet El-Nasr city; Dakahlia; Egypt.

Time of study:

This study was started in October 2009 and extended to April 2010.

\section{Design of work:}

A questionnaire was designed to collect data including 24 hours recall of dietary intake for 7 days according to (El-Wardany 2010).

\section{Methods:}

The questionnaire was done by interviewing and the students them selves. Questionnaire expressed the food intake for the previous 24 hours recall included basic meals namely, (breakfast, lunch and dinner) and between meals. The recalls were done for 7 days, our obtained data were calculated according to Diet Analysis Program (1995) in food laboratory, Home Economics Faculty, Menofiya University; Egypt.

Recommended Dietary Allowances (R.D.A): status.

Results were compared with R.D.A (1989) to evaluate the nutrition

\section{RESULTS AND DISCUSSION}

Nutritional status of preparatory school students aged from 12-15 years using 24 hours recall method was determined.

Food intake content of energy $\left(\mathrm{K}_{\mathrm{cal}}\right)$, protein, fat, carbohydrate, vitamins and minerals in compare with Recommended Dietary Allowances was analysed.

Data presented in Table (1) demonstrated the means and standard deviation of nutrients for students aged (12:15) years. Results indicated that the amount of energy for male was $1415.65 \pm 43.00 \mathrm{~K}$ cal and this amount could 
not cover the requirements of energy in compare with Recommended Dietary Allowances (RDA.1989), which was $2500 \mathrm{~K}$ calday (56.62\% of RDA), while the amount of energy for female was $1198 \pm 14.58 \mathrm{~K}_{\text {cal }}$ and RDA value was $2200 \mathrm{~K}_{\text {cal }} /$ day $(54.64 \%$ of RDA). These results are in accordance with (Franz et al., 2002).

Results in the same Table indicated that the amount of protein from animal, plant and total protein consumed by males were $33.09 \pm 6.28$, $29.82 \pm 1.32$ and $62.91 \pm 1.93 \mathrm{gm}$ respectively, while with females were $22.42 \pm 1.09,24.95 \pm 0.86$ and $47.37 \pm 1.59$ respectively. Total protein intake for the studied sample was higher than RDA for both sexes. The percentages of total protein were $139.8 \%$ and $102.97 \%$ of RDA for male and female respectively. These results were nearly agree with Wiltshire et al., (2003).

It could be detected from the Table (1) that, mean of animal fat consumed by males and females were $24.07 \pm 1.28$ and $18.30 \pm 1.13 \mathrm{gm}$ respectively. While plant fat consumed by males and females were $23.43 \pm 1.25$ and $19.43 \pm 1.11$ gm respectively.

Data presented in Table (1), showed also that carbohydrates consumed by males was (191.33 \pm 5.48$)$ higher than those consumed by females $(171.67 \pm 4.15) \mathrm{gm}$. Carbohydrates intake was higher than RDA for both sexes, which represented $147.17 \%$ and $132.05 \%$ of RDA for male and female respectively.

Also, in the same Table it was detected that mean of fiber consumed is $16.13 \pm 0.31 \mathrm{gm}$ for males and $14.48 \pm 0.31$ for females.

Table (1): Nutrients intake for the students aged (12:15) years.

\begin{tabular}{|c|c|c|c|c|c|c|c|c|}
\hline \multirow[b]{2}{*}{ Nutrients sex } & \multicolumn{3}{|c|}{ Male } & \multicolumn{3}{|c|}{ Female } & \multirow[b]{2}{*}{ T test } & \multirow{2}{*}{ 홍 } \\
\hline & Amount & $\begin{array}{c}\text { RDA } \\
\text { value }\end{array}$ & RDA $\%$ & Amount & $\begin{array}{c}\text { RDA } \\
\text { value }\end{array}$ & RDA\% & & \\
\hline Energy (kcal) & $1415.65 \pm 43.00$ & 2500 & 56.62 & $1198.20 \pm 14.58$ & 2200 & 54.40 & $-.851-$ & - \\
\hline Animal protein $(\mathrm{gm})$ & $33.09 \pm 6.28$ & - & - & $22.42 \pm 1.09$ & - & - & 1.674 & - \\
\hline Plant protein (gm) & $29.82 \pm 1.32$ & - & - & $24.95 \pm 0.86$ & - & - & 3.083 & ** \\
\hline Total protein $(\mathrm{gm})$ & $62.91 \pm 1.93$ & 45 & 139. 8 & $47.37 \pm 1.59$ & 46 & 102.97 & 3.535 & ** \\
\hline Animal fat (gm) & $24.07 \pm 1.28$ & - & - & $18.30 \pm 1.13$ & - & \begin{tabular}{|c|}
- \\
\end{tabular} & 3.368 & ** \\
\hline Plant fat (gm) & $23.43 \pm 1.25$ & - & - & $19.43 \pm 1.11$ & - & - & 2.381 & * \\
\hline Total fat (gm) & $47.5 \pm 1.96$ & - & - & $37.73 \pm 1.76$ & - & - & 3.579 & ** \\
\hline Carbohydrate (gm) & $191.33 \pm 5.48$ & 130 & 147.17 & $171.67 \pm 4.15$ & 130 & 132.05 & 2.857 & ** \\
\hline Fiber (gm) & $16.13 \pm 0.50$ & - & - & $14.48 \pm 0.31$ & - & - & 2.779 & ** \\
\hline
\end{tabular}

Results illustrated in Table (2) showed that the means and standard deviations of several vitamins: fat soluble vitamins namley (A, D, E and K) and water soluble vitamins namley $\left(C, B_{1}, B_{2}, N i a c i n, B_{6}, B_{12}\right.$ and Folate) intake for males and females in compare with RDA (1989).

Results showed that the amount of vitamin $\mathrm{A}$ was higher in males than females it was $269.17 \pm 14.80$ and $210.80 \pm 14.58 \mathrm{mg}$ respectively. The percentages were $26.91 \%$ and $26.35 \%$ of RDA respectively, this amount consumed was very lower than RDA for both sexes. 
Abd El-Gawwad, A. I. et al.

The results for vitamin A were compared with the Dietary reference intake for children 2 to 8 years old $(400 \mathrm{mg} /$ day) and children 9 to 13 years old (600 mg/day) (Food and Nutrition Board, 2001).

According to (FAO 2003) vitamin A deficiency among preschoolers and their mothers is considered to be sub-clinical, mild-to-moderate, public health problem in Egypt.

Fishman et al., (2000) reported that children with a marginal or deficient vitamin A status had a significantly higher risk for iron deficiency anemia. Vitamin $A$ is essential for the production of red blood cells and vitamin $\mathrm{C}$ protects mature red blood cells against oxidation and promotes iron absorption.

Results in the table (2) showed that the mean of vitamin $\mathrm{C}$ consumed by males was $(35.36 \pm 9.45 \mathrm{mg})$ higher than females $(18.43 \pm 1.09 \mathrm{mg})$. The percentages were $70.72 \%$ and $36.86 \%$ of RDA respectively. Vitamin C intake for the studied sample was lower than recommended dietary allowances for both sexes.

It could be observed that mean of vitamin $D$ consumed by males was $(2.76 \pm 0.65 \mathrm{mg})$ higher than females $(1.36 \pm 0.86 \mathrm{mg})$. The percentages were $27.60 \%$ and $13.60 \%$ of RDA for male and female respectively. Vitamin D intake for the studied sample was very lower than recommended dietary allowances.

It was noticed that mean of vitamin $\mathrm{E}$ consumed by males was $(9.44 \pm 0.87 \mathrm{mg})$ higher than females $(9.27 \pm 1.59 \mathrm{mg})$. Vitamin $E$ intake for the males was lower than recommended dietary allowances $(94.4 \%)$ but for females was higher than recommended dietary allowances(115.87\%).

Results for water soluble vitamins indicated that, vitamin $B_{1}$ consumed by males was $(1.15 \pm 0.24 \mathrm{mg})$ higher than females $(0.70 \pm 1.13 \mathrm{mg})$. The percentages were $88.46 \%$ and $63.63 \%$ of RDA, respectively. So, vitamin $B_{1}$ intake for the both of male and female was lower than recommended dietary allowances.

It was noticed that mean of vitamin $B_{2}$ consumed by males was $(1.68 \pm 0.04 \mathrm{mg})$ higher than females $(1.53 \pm 1.11 \mathrm{mg})$. Vitamin $B_{2}$ intake for the studied sample was higher than recommended dietary allowances for both sexes. The percentages were $112 \%$ and $117.69 \%$ of RDA respectively.

From Table (2), the mean of niacin consumed by males was $(9.46 \pm 0.42 \mathrm{mg})$ higher than those of females $(7.95 \pm 1.76 \mathrm{mg})$. The percentages were $55.64 \%$ and $53 \%$ of RDA respectively. Niacin intake for the studied sample was lower than RDA for male and female.

Data showed that means of vitamin $B_{6}$ consumed by males was $1.06 \pm 0.03$ and $0.94 \pm 4.15 \mathrm{mg}$ for female. It was The percentages were $62.35 \%$ and $67.14 \%$ of RDA respectively. This amount consumed was lower than those of recommended dietary allowances.

For vitamin $B_{12}$ results in Table (2) showed that the amount of it consumed by males was $(2.40 \pm 0.10 \mathrm{mg})$ higher than females $(2.10 \pm 0.31$ $\mathrm{mg}$ ). The percentages were $120 \%$ and $105 \%$ of RDA respectively. Vitamin B12 intake for the studied sample was higher than recommended dietary allowances for males and females. 
It was also noticed that mean of folate consumed by males was $(328.28 \pm 42.35 \mathrm{mg})$ higher than females $(216.99 \pm 1.09 \mathrm{mg})$. The percentages were $218.85 \%$ and $144.66 \%$ of RDA respectively. Folate intake for the studied sample was very higher than recommended dietary allowances for samples.

Table (2): Vitamins intake for the students aged (12:15) years.

\begin{tabular}{|c|c|c|c|c|c|c|c|c|}
\hline \multirow{2}{*}{$\begin{array}{l}\text { sex } \\
\text { Vitamin } \\
(\mathrm{mg})\end{array}$} & \multicolumn{3}{|c|}{ Male } & \multicolumn{3}{|c|}{ Female } & \multirow[b]{2}{*}{$T$ test } & \multirow[b]{2}{*}{ Sig. (2 tailed) } \\
\hline & Amount & $\begin{array}{c}\text { RDA } \\
\text { value } \\
\end{array}$ & RDA\% & Amount & $\begin{array}{c}\text { RDA } \\
\text { value }\end{array}$ & RDA $\%$ & & \\
\hline Vitamin A & $269.17 \pm 14.80$ & 1000 & 26.91 & $210.80 \pm 14.58$ & 800 & 26.35 & 3.110 & ** \\
\hline Vitamin C & $35.36 \pm 9.45$ & 50 & 70.72 & $18.43 \pm 1.09$ & 50 & 36.86 & 1.727 & - \\
\hline Vitamin D & $2.76 \pm 0.65$ & 10 & 27.6 & $1.36 \pm 0.86$ & 10 & 13.60 & 2.082 & * \\
\hline Vitamin E & $9.44 \pm 0.87$ & 10 & 94.40 & $9.27 \pm 1.59$ & 8 & 115.87 & .143 & - \\
\hline Vitamin B1 & $1.15 \pm 0.24$ & 1.3 & 88.46 & $0.70 \pm 1.13$ & 1.1 & 63.63 & 1.835 & - \\
\hline Vitamin B2 & $1.68 \pm 0.04$ & 1.5 & 112 & $1.53 \pm 1.11$ & 1.3 & 117.69 & 2.460 & * \\
\hline Niacin & $9.46 \pm 0.42$ & 17 & 55.64 & $7.95 \pm 1.76$ & 15 & 53 & 3.137 & ** \\
\hline Vitamin B6 & $1.06 \pm 0.03$ & 1.7 & 62.35 & $0.94 \pm 4.15$ & 1.4 & 67.14 & 2.764 & ** \\
\hline Vitamin B12 & $2.40 \pm 0.10$ & 2 & 120 & $2.10 \pm 0.31$ & 2 & 105 & 1.890 & - \\
\hline Folate & $328.28 \pm 42.35$ & 150 & 218.85 & $216.99 \pm 1.09$ & 150 & 144.66 & 2.549 & * \\
\hline
\end{tabular}
$\left({ }^{\star}\right) \mathrm{P}<0.05$
$\left(^{* *}\right) \mathrm{P}<0.01$
$\left.{ }^{* * \star}\right) \mathrm{P}<.0001$
(-) Negative Correlation

Results in Table (3) showed the amount of several minerals namely $\mathrm{Ca}, \mathrm{P}, \mathrm{Fe}, \mathrm{Na}, \mathrm{K}, \mathrm{Zn}$ and $\mathrm{Mg}$ intake for males and females compared with RDA (1989).

Data showed that a significant diffuseness observed in the amount of Calcium intake in both of male and female were $533.99 \pm 28.53$ and $424.20 \pm 27.50 \mathrm{mg}$, and its percentages were $44.49 \%$ and $35.35 \%$ of RDA respectively. Calcium intake for the studied sample was very lower than RDA.These results were in accordance with (Michaelsen, 2003).

Results showed that, means of phosphorus intake for males were $907.32 \pm 28.21 \mathrm{mg}$ and females $777.55 \pm 24.45 \mathrm{mg}$, and percentages were $75.60 \%$ and $64.79 \%$ of RDA. Phosphorus intake for males and females was lower than recommended dietary allowances for both sexes.

Moreover, means of iron from animal, plant sources and total iron consumed by males were $4.01 \pm 0.17,8.99 \pm 0.50$ and $13.00 \pm 0.56 \mathrm{mg}$, respectively while with females were $3.40 \pm 0.17,7.28 \pm 0.37$ and $10.68 \pm 0.44 \mathrm{mg}$, respectively. The percentages of total iron were $108.33 \%$ and $71.20 \%$ of RDA respectively for males and females. Total iron intake for males was higher than recommended dietary allowances but for females was lower than recommended dietary allowances.

Results indicated that the Sodium intake were lower content in female in compare with males $(1271.09 \pm 54.77$ and $1670.22 \pm 83.78 \mathrm{mg})$ respectively and its percentages were $334 \%$ and $254.21 \%$ of RDA respectively. Sodium intake for the studied sample was very higher than recommended dietary allowances.

It was found that, mean of potassium intake for males were $1647.10 \pm 169.97 \mathrm{mg}$ higher than females $1182.27 \pm 44.62 \mathrm{mg}$. 
Abd El-Gawwad, A. I. et al.

Table (3) indicated that, the Zinc intake for males was $7.77 \pm 0.20 \mathrm{mg}$ and $6.95 \pm 0.18 \mathrm{mg}$ for females. Zinc intake for the studied sample was lower than recommended dietary allowances for both sexes, and its percentages were $51.80 \%$ for male and $57.91 \%$ for female of RDA.

Data indicated that, mean of magnesium intake for males was $306.52 \pm 10.16 \mathrm{mg}$ higher than females $265.82 \pm 7.88 \mathrm{mg}$, and its percentages were $113.52 \%$ and $94.93 \%$, for males and females respectively. Magnesium intake for males was higher than recommended dietary allowances but for females was lower than recommended dietary allowances.

Hassan and Amin (2004) reported that the most deficient nutrient was calcium (only $22.1 \%$ consumed $100 \%$ of the RDA), followed by calories $(26.4 \%)$, vitamin C $(39.1 \%)$ and niacin $(44.8 \%)$. The least deficient nutrient was protein $(98 \%$ consumed $100 \%$ of the RDA), followed by vitamin b2 $(71 \%)$ and vitamin $\mathrm{A}(60.3 \%)$.

Table (3): Minerals intake for the students aged (12:15) years.

\begin{tabular}{|l|c|c|c|c|c|c|c|c|}
\hline \multirow{2}{*}{$\begin{array}{l}\text { Mineral } \\
\text { (mg) }\end{array}$} & \multicolumn{4}{|c|}{ Male } & \multicolumn{3}{c|}{ Female } & \\
\cline { 2 - 9 } & Amount & $\begin{array}{c}\text { RDA } \\
\text { value }\end{array}$ & RDA\% & Amount & $\begin{array}{c}\text { RDA } \\
\text { value }\end{array}$ & RDA\% & T test & Sig. (2 tailed) \\
\hline calcium & $533.99 \pm 28.53$ & 1200 & 44.49 & $424.20 \pm 27.50$ & 1200 & 35.35 & 2.770 & ${ }^{* *}$ \\
\hline Phosphorus & $907.32 \pm 28.21$ & 1200 & 75.61 & $777.55 \pm 24.45$ & 1200 & 64.79 & 3.476 & ${ }^{* * *}$ \\
\hline Animal iron & $4.01 \pm 0.17$ & - & - & $3.40 \pm 0.17$ & - & - & 2.450 & ${ }^{*}$ \\
\hline Plant iron & $8.99 \pm 0.50$ & - & - & $7.28 \pm 0.37$ & - & - & 2.720 & ${ }^{* *}$ \\
\hline Total iron & $13.00 \pm 0.56$ & 12 & 108.33 & $10.68 \pm 0.44$ & 15 & 71.20 & 3.245 & ${ }^{* *}$ \\
\hline Sodium & $1670.22 \pm 83.78$ & 500 & 334 & $1271.09 \pm 54.77$ & 500 & 254.21 & 3.987 & ${ }^{* * *}$ \\
\hline Potassium & $1647.10 \pm 169.97$ & - & - & $1182.27 \pm 44.62$ & - & - & 2.645 & ${ }^{* *}$ \\
\hline Zinc & $7.77 \pm 0.20$ & 15 & 51.80 & $6.95 \pm 0.18$ & 12 & 57.91 & 2.979 & ${ }^{* *}$ \\
\hline Magnesium & $306.52 \pm 10.16$ & 270 & 113.52 & $265.82 \pm 7.88$ & 280 & 94.93 & 3.163 & ${ }^{* *}$ \\
\hline
\end{tabular}

$\begin{array}{llll}\left(^{\star}\right) \mathrm{P}<0.05 & \left.{ }^{\star *}\right) \mathrm{P}<0.01 & \left(^{\star * \star}\right) \mathrm{P}<.0001 & (-) \text { Negative Correlation }\end{array}$

\section{REFERENCES}

Brustad M, Skeie G, Braaten T, Slimani N \& Lund E (2003). Comparison of telephone vs face-to-face interviews in the assessment of dietaryintake by the $24 \mathrm{~h}$ recall EPIC SOFT program - the Norwegian calibration study. Eur J Clin Nutr 53, 107-113.

El- Wardany, N.A. (2010). The Nutritional Status Of Primary School Children In Alexandria Governorate. Faculty of Specific Education Department of Home Economics Tanta University.

FAO (2003). Nutrition Country Profiles - Egypt. FAO, Rome, Italy. http://www. fao. org/aq/aqn/nutntion/egy-e, stm

Fishman, S.M., Christian, P. and West, K.P. (2000). The role of vitamins in the prevention and control of anemia. Public Health Nutr, 3(2): 121 50.

Food and Nutrition Board, institute of medicine (2001). Dietary reference intake for Zinc and Vitamin A. Y; Washington, DC, National Academies Press. 
Franz, M.J., Beebe, C.A., Brunzell, J.D., chiasson, J.L., Garge, A., Holzmeister., L.A., Hoogwerf, B., MayerDavis, E., Mooradian, A.D., Purnell, J.Q. and Wheeler, M. (2002). Evidence-Based Nutrition principles and recommendations for the treatment and prevention of diabetes and related complications. Diabetes Care, 25: 148.

Hassan M.H. and Amin, E.K.(2004): An intervention programmer for improving the nutritional status of children 2-5 aged years in Alexandria. Eastern Mediterranean Health Journal Vol.10 no6,828.

Lifhithz, F., Tarim, O., and Smith, M.M. (1993). Nutrition in adolescence. Endocr Metab Clinics North Amer; 22:673-83.

Michaelsen K.F. (2003). Feeding and nutrition of infants and young children. Guidelines for the WHO European Region, with emphasis on the former Soviet countries. WHO Regional Publications, Denmark, European Series, NO.87: page 9-10, 45, 217.

Owen, A.Y and Frankle, R.T (1986). "Nutrition in the community, the Art of Delivering Services" Times Mirror, Mosby College Publishing St. Louis Toronto, Santo Clog.

Perry, C. (2000). Lifecycle III: preadolescent and adolescent influences on health. In The Institute of Medicine Symposium: capitalizing on social science and behavioral research to improve the public's health. Atlanta, G A: National Academy of Sciences press.

Pipes, P.L. (1989), "Nutrition in infancy and childhood" Times Mirror/ Mosby College Publishing St. Louis, Toronto, Boston, Los Altos.

RDA (1989). Recommended Dietary Allowances. The National Academy of sciences, National Academy Press, $10^{\text {th }}$ Ed., Washington, D.C.

Story, M. (1992). Nutritional Requirements during Adolescence. Textbook of adolescent medicine. Philadelphia, PA:W. B. Saunders.

Wiltshire, E.J., Hirte, C, and Couper, J.J. (2003). Dietary Fats Do Not Contribute to Hyperlipidemia in children and Adolescents with type 1Diabetes. Diabetes care, 26: 1356. 


\section{Abd El-Gawwad, A. I. et al.}

استخدام طريقة استرجاع غذاء ؛ ؟ ساعة في دراسة الحالة الغذائية لطلاب المرحلة

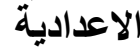
عبد الحميد إبراهيم عبد الجواد* ، جميل حبيب محمد حبيب** ، شادى محمد الثهاوى* و

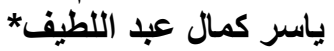

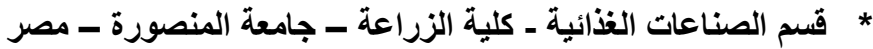
** قسم الاقتصاد المنزلى - كلية التربية النوعية - جامعة طنطا - مصرة

يهدف هذا البحث إلى دراسـة الحالـة الغذائية لطلاب المرحلة الإعداديـة وذلك باستخدام

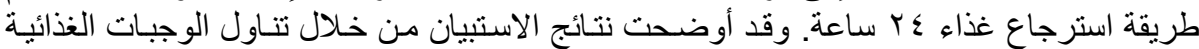

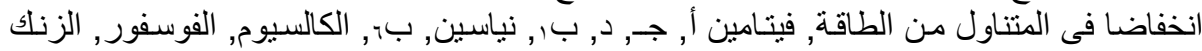

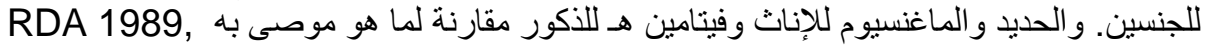

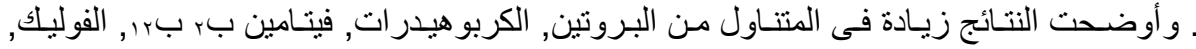

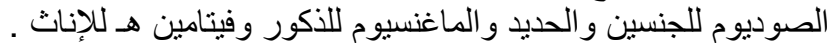

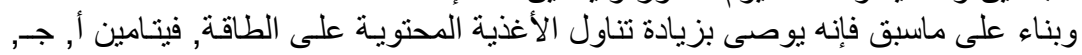

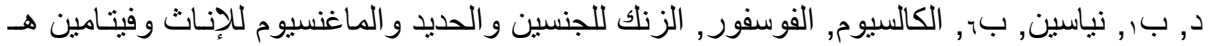

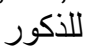

كلية الزراعة - جامعة المنصورة

كلية الزراعة بلمياط - جامعة المنصورة

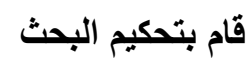

أ.د / مسعد عبد العزيز ابو ريا أ.د / ارزق احمد الدنجاوى العزيز ابو ري 